\title{
GEGEVENS OVER LAND EN VOLK VAN SURINAME
}

\author{
DOoR C. VAN COLL, \\ Missionaris in West-Indië.
}

\section{N L E I D I N G. a)}

Wij bieden den welwillenden Lezer bij deze aan, een tweede, vermeerderde en verbeterde uitgave van onze "Grepen in de Landen Volkenkunde van Suriname" die 8 à 9 jaar geleden, het eerst als feuilleton het licht zagen in het Zondagsblad "De Surinamer".

Wie zich een denkbeeld kan vormen van den geographischen toestand van Guiana, zal gaarne toegeven, dat het onzerzijds ondoenlijk zou geweest zijn meer dan Gegevens-over Land- en Volkenkunde te verzamelen. Om slechts de Plantenkunde alleen te noemen: welke tochten door het wilde bosch, - welk eene karavaan van Negers en Indianen, in staat aanwijzingen te doen en het inlandsch gebruik van kruiden en planten te verklaren, - welke

a) $\mathrm{Bij}$ de toenemende belangstelling voor Suriname, welke zich in de laatste tijden gelukkig in ons land openbaart, achten wij het een groot voorrecht, door den geachten Schrijver, die ginds meer dan dertig jaren als missionaris werkzaam was, in staat te zijn gisteld, een helder overzicht te geven van de daar levende bevolking.

Als schrijver van de „Zeden en gewoonten der Indianen in onze Nederlandsche kolonie Suriname (Gulpen, 1886, - thans uitverkocht) mag Pater van Coll ongetwijfeld gerekend worden onder hen die dienaangaande recht van spreken bezitten.

Gelijk de Schrijver in zijne Inleiding uiteenzet, is het stuk, dat hier wordt medegedeeld, niet nieuw; in hoofdzaak werd het reeds als feuilleton afgedruk: in "De. Surinamer" van 6 Jan. 1894-28 Juni 1896. Het. Instituutsbestuur achtte dit geen bezwaar om het, door den Schrijver herzien, in zijne Bijdragen op te nemen.

Dat Pater van Coll op versehillende plaatsen zich dicht aansluit bij de mededeelingen van Kappler over Surinam (Stuttgart 1887) en van Crevaux (Voyages dans l'Amérique du Sud) (Paris 1883) kan ieder vermoeden, die de hulde leest, door den Schrijver in zijne Inleiding aan deze twee mannen betuigd; enkele gedeelten werden, gelijk hier en daar nader is aangegeven, min of meer rechtstreeks overgenomen.

RED. DER BiJdRAgen.

7e Volgr. I. 
belezen- en bedrevenheid in den onderzoeker zouden gevorderd worden om eene ook maar eenigszins volledige Flora te leveren van Suriname, waarvan nog zoo weinig bekend is!

Voeg hierbij de moeielijkheden verbonden aan het onderzoek naar de bodemgesteldheid, aan eene beschrijving van het dierenrijk en vooral aan een gezette studie van de zeden en gewoonten van die Indianen, welke niet met ons in verkeer staan, en men begrijpt, dat niet slechts hooge kennis, maar ook een gestel van ijzer en vrije beschikking over schatten gouds noodzakelijk zouden zijn voor hem, die zich tot taak stelde de Land- en Volkenkunde van Suriname volledig te behandelen. En daar ons van dat alles veel ontbrak, hebben wij slechts gegevens bijeengebracht. Bijeengebracht echter, telkenmale als de bediening van 't zielenheil, ons toevertrouwd, er de gelegenheid toe aanbood.

Ons doel was: èn nuttig te zijn voor Vaderland en Kolonie, èn ons zelven te bekwamen in de kennis van het volk, dat wij te bekeeren en christelijk te beschaven hebben. Zoo voor iemand, dan is voor ons deze kenuis eene eerste behoefte.

Wij hebben gegevens verzameld, met eigen oog en oor alleen, waar wij zelven zien en hooren konden: zelfs hebben wij niet geschroomd, volgens het dus verkregen oor- en ooggetuigenis de dingen te beschrijven, al mochten dan andere schrijvers er ook juist het tegendeel van gedacht hebben. In zoover is dit boek geheel oorspronkelijk.

Waar wij echter uit eigen zien en hooren niet konden spreken, raadpleegden wij naar ons beste weten de Geschiedenis, alsmede de jongste Beschrijvingen.

Aan Kappler en Crevaux daarbij hulde en waardeering!

Dank, oprechten dank voorts aan Dr. H. D. Benjamins, Inspecteur van het Onderwijs, die zoo beleefd was de Koloniale Bibliotheek steeds voor ons open te stellen; dank ook aan allen, die zich met de correctie hebben willen belasten.

Waar wij gefaald hebben, moge de Lezer ons verschoonen!

En dan na ruim dertig jaren nog altoos dezelfde bede: het Godsrijk kome over Suriname! 